\title{
Beina- og liðasýkingar barna á Íslandi af völdum baktería á tímabilinu 1996-2005
}

\section{Ásgeir Pór Másson læknir $^{1}$}

Pórólfur Guð̃nason barnalæknir og sérfræðingur í smitsjúkdómum barna ${ }^{1,2,3}$

\section{Guð̌mundur K. Jónmundsson} barnalæknir ${ }^{1,2}$

\section{Helga Erlendsdóttir} lífeindafræðingur ${ }^{1,4}$

\section{Karl G. Kristinsson} sérfræðingur í sýklafræðij ${ }^{1,4}$

Már Kristjánsson

lyflæknir og sérfræðingur í smitsjúkdómum ${ }^{5}$

\section{Ásgeir Haraldsson barnalæknir og sérfræđingur í ónæmisfræði barna ${ }^{1,2}$}

Lykilorð: Beinasýkingar, liðasýkingar, Staphylococcus aureus, Kingellae kingae, börn.

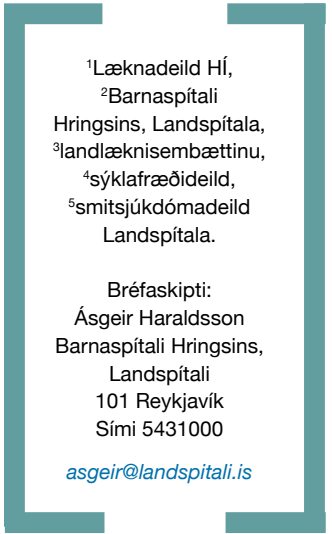

\section{Ágrip}

Tilgangur: Markmið rannsóknarinnar var að kanna nýgengi, sýkingarvalda, einkenni og greiningaraðferðir beina- og liðasýkinga í börnum á Íslandi.

Efniviður og aðferðir: Rannsóknin var afturskyggn og náði til barna yngri en 18 ára sem lögðust inn vegna sýkinganna á tímabilinu 19962005. Upplýsingum var safnað úr sjúkraskrám. Tilfellum var skipt í prjá jafna aldurshópa, 0-5 ára, 6-11 ára og 12-17 ára. Niðurstöður ræktana voru metnar og einnig breytingar á nýgengi á tímabilinu.

Niðurstöður: Á tímabilinu greindust 220 tilfelli, 161 með beinasýkingu og 59 með liðasýkingu. Nýgengi jókst marktækt á tímabilinu $(\mathrm{p}=0,019)$. Nýgengisaukningin var nær eingöngu bundin við beinasýkingar hjá yngsta aldurshópnum. Nýgengi par sem ræktun var jákvæð breyttist ekki en nýgengi með neikvæða ræktun jókst marktækt $(p<0,001)$. Miðgildi aldurs sjúklinga með beinasýkingar (6,1 ára) var hærri en peirra með liðasýkingar ( 1,8 ára) $(\mathrm{p}=0,003)$. I $59 \%$ beinasýkinga og $44 \%$ liðasýkinga greindist baktería, S. aureus var algengust (65\% beinasýkinga og 27\% liðasýkinga), pví næst K. kingae (7\% beinasýkinga og 11\% liðasýkinga). Methicillinónæmir S. aureus greindust ekki. Sköflungur $(20 \%)$ og hnéliður $(47 \%)$ voru algengustu staðir sýkinganna.

Ályktanir: Rannsóknin varpar ljósi á mikilvæga pætti beina- og liðasýkinga á Íslandi. Nýgengið vex í yngsta aldurshópnum, einkum par sem ræktun er neikvæð. Algengasti orsakavaldur er $S$. aureus, svo K. kingae. Meðalaldur, kynjahlutfall og staðsetning sýkinga er sambærilegt við erlendar rannsóknir. Pörf er á næmari sýklafræðilegum greiningaraðferðum hjá peim sem eru með neikvæðar ræktanir.

\section{Inngangur}

Beina- og liðasýkingar í börnum verða oftast vegna blóðborinna sýkinga en sjaldnar vegna dreifingar frá nærliggjandi vefjum. ${ }^{1,2}$ Beinasýking af völdum blóðborinnar sáningar verður oftast í fal (metaphysis) langra beina. Háræðar beinfalsins eru margar og enda í stórum bláæðastokkum (venous sinusoids) sem eru án átfrumnalags. Lítill áverki á beinfalinn getur valdið litlum margúl (hematoma) inni í beini sem getur orsakað beindrep. ${ }^{3}$ Slíkt svæði er kjörlendi fyrir blóðborna sáningu. ${ }^{4}$ Í börnum eru vaxtarlínur langra beina opnar og staðsettar í beinfalnum. Skemmd í vaxtarlínu, til dæmis í kjölfar sýkingar, getur valdið varanlegri vaxtarskerðingu. ${ }^{3,5}$

Flest tilfelli beinasýkinga eru einskorðuð við eitt bein. Sýkingar í fleiri en einu beini koma fyrir í um 10\% tilfella. ${ }^{1,6}$ Í erlendum rannsóknum er lærleggur algengasti sýkingarstaður en sköflungur fylgir fast á eftir.1, 6,7 Sýkingar eru algengari 1 stórum en smáum liðum og eru hnéliður og mjaðmaliður einkum útsettir. ${ }^{7}$ Staphylococcus aureus veldur $64-76 \%$ beinasýkinga og 38-48\% liðasýkinga í flestum rannsóknum. ${ }^{6-9}$ Kóagúlasaneikvæðir staphýlókokkar, streptókokkar og Kingella kingae koma sjaldnar fyrir í beina- og liðasýkingum ${ }^{7,}{ }^{10}$ en sú síðastnefnda greinist í vaxandi mæli í liðasýkingum erlendis og á Íslandi. ${ }^{8-12}$ Áður fyrr var algengt að gefa sýklalyf í æð í 4-8 vikur. ${ }^{13,14}$ Nýlegar rannsóknir benda hins vegar til að gjöf sýklalyfja í æð í styttri tíma (eina til tvær vikur) fylgt eftir með gjöf um munn í lengri tíma sé fullnægjandi meðferð. ${ }^{15,16}$

Mikilvægt er að rétt sé staðið að meðferð sýkinga í liðum og beinum til að komast hjá alvarlegum afleiðingum peirra. Liður í pví er að pekkja hvaða sjúkdómsvaldar orsaka beinaog liðasýkingar hér á landi til að beita megi markvissri meðferð. Markmið rannsóknarinnar sem er lýsandi faraldsfræðilegs eðlis var að kanna nýgengi, sýkingarvalda og rannsaka einkenni og greiningaraðferðir beina- og liðasýkinga í börnum á Íslandi á tímabilinu 1996-2005.

\section{Efniviður og aðferöir}

Rannsóknin var afturskyggn lýsandi faraldsfræðileg rannsókn. Hún náði til allra barna frá fæðingu að 18 ára aldri sem lögðust inn á Barnaspítala Hringsins, barnadeild Sjúkra- 
Tafla I. Samanburður á einstaklingum (beina- og liðasýkingar) með jákvæðar og neikvæðar ræktanir með tilliti til einkenna, blóð- og myndrannsókna, árstíða og aldurs.

\begin{tabular}{|c|c|c|}
\hline & $\begin{array}{l}\text { Tilfelli með jákvæða } \\
\text { ræktun } \mathrm{N}=121\end{array}$ & $\begin{array}{l}\text { Tilfelli með neikvæða } \\
\text { ræktun } \mathrm{N}=99\end{array}$ \\
\hline \multicolumn{3}{|c|}{ Myndrannsóknir (jákvæðar/framkvæmdar) } \\
\hline Röntgenmynd & $36 / 99(36 \%)$ & $31 / 83(37 \%)$ \\
\hline Ísótóparannsókn & $80 / 85(94 \%)$ & $60 / 67(90 \%)$ \\
\hline Segulómun & $21 / 21(100 \%)$ & $20 / 21(95 \%)$ \\
\hline Ómun & $16 / 37(44 \%)$ & $7 / 19$ (37\%) \\
\hline \multicolumn{3}{|l|}{ Blóðrannsóknir (miðgildi (spönn)) } \\
\hline Hvít blóðkorn (x10\%/L) & $10,2(3,9-25,9)$ & $12,0(4,9-32,1)$ \\
\hline $\mathrm{CRP}(\mathrm{mg} / \mathrm{L})$ & $33(0-194)$ & $22(0-232)$ \\
\hline Sökk (mm/klst) & $30(1-102)$ & $29(1-90)$ \\
\hline \multicolumn{3}{|l|}{ Einkenni } \\
\hline Lengd einkenna (miðtala (spönn)) & $6(0-365)$ dagar $^{\dagger}$ & $8(0-74)$ dagar \\
\hline Hiti ${ }^{\circ} \mathrm{C}$ (miðgildi (spönn)) & $38,2(36,2-40,7)$ & $37,8(36,0-40,2)$ \\
\hline Verkur & $111 / 121(92 \%)$ & 89/99 (92\%) \\
\hline Starfsbilun & 108/121 (89\%) & 89/99 (92\%) \\
\hline Bólga & $67 / 121(55 \%)$ & $50 / 99(52 \%)$ \\
\hline Roði & $47 / 121(39 \%)$ & $36 / 99(37 \%)$ \\
\hline \multicolumn{3}{|l|}{ Faraldsfræði } \\
\hline Aldur (miðgildi (spönn)) & 8,5 ár $(0,1-17,7)^{*}$ & 1,8 ár $(0,7-17,0)^{*}$ \\
\hline Tilfelli undir fjögurra ára & $34 \%$ & $71 \%$ \\
\hline Tilfelli um haust & $32 \%$ & $41 \%$ \\
\hline
\end{tabular}

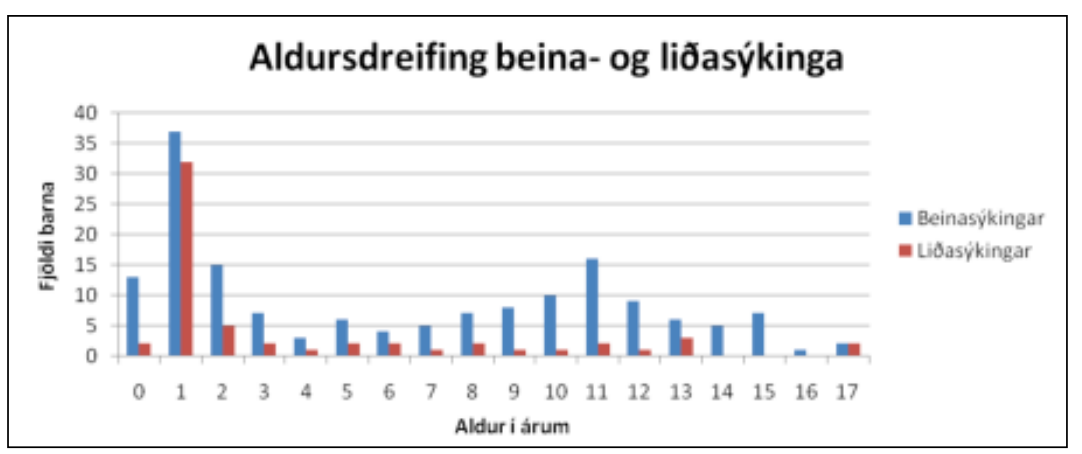

Mynd 1. Aldursdreifing barna með beinasýkingar og liðasýkingar.

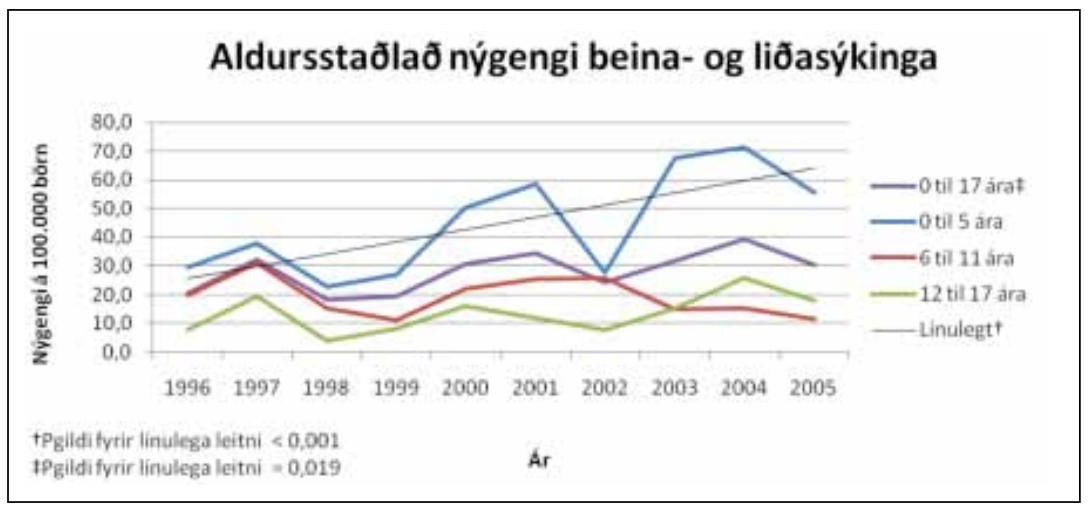

Mynd 2. Aldursstaðlað nýgengi beina- og liðasýkinga 1996-2005. húss Reykjavíkur eða Sjúkrahúsið á Akureyri frá ársbyrjum 1996 til ársloka 2005 með sjúkdómsgreininguna sýking í beini eða lið. Framangreindar stofnanir eru pær einu á landinu sem greina og meðhöndla slíkar sýkingar og pví nær rannsóknin til allrar pjóðinnar á tímabilinu.

Inntökuskilyrði rannsóknarinnar byggðu á ICD-9 (711 og 730) og ICD-10 (M00, M01, M46, M86 og M90) greiningarkóðum. Leitað var að einstaklingunum í sjúkraskrám stofnananna. Sjúklingar sem pannig fundust purftu ennfremur að uppfylla tvennskonar skilyrði; að hafa fengið fulla meðferð í samræmi við beina- eða liðasýkingu og að uppfylla að minnsta kosti eitt af eftirfarandi: jákvæða ræktun (blóð, liðvökvi eða bein), myndrannsókn sem samrýmdist beina- eða liðasýkingu eða að hafa klínísk einkenni beina- eða liðasýkingar. Til að tryggja að öll tilfelli væru með í rannsókninni var einnig farið yfir niðurstöður ræktana (liðvökvi og beinvefur) frá börnum í gagnagrunni sýklafræðideildar Landspítala.

Eftirfarandi upplýsingum var safnað úr sjúkraskrám; aldur, kyn, einkenni og staðsetning sýkingarinnar, greiningarkóði og greiningardagsetning, atriði sem komu fram í skoðun, niðurstöður blóðrannsókna, myndrannsókna og ræktana. Greiningardagur (dagur 0) var skilgreindur pegar sjúklingur fékk fyrstu gjöf sýklalyfja í æð. Sótthiti var skilgreindur $\geq 38^{\circ} \mathrm{C}$ mælt í endaparm. Framangreindum upplýsingum var safnað í skrá par sem persónueinkenni höfðu verið afmáð í samræmi við leyfi Vísindasiðanefndar og Persónuverndar.

Við úrvinnslu gagna var börnunum skipt í hópa. Í fyrsta lagi eftir pví hvort um var að ræða beinasýkingu eða liðasýkingu. Peir sem höfðu bæði beinasýkingu og liðasýkingu í aðlægum lið voru flokkaðir með beinasýkingum. ${ }^{6}$ Í öðru lagi var tilfellum skipt í prjá jafna aldursflokka, 0-5 ára, 6-11 ára og 12-17 ára, til að meta nýgengi beina- og liðasýkinga eftir aldurshópum. Tölur um fjölda barna í einstökum aldursflokkum á Íslandi voru fengnar hjá Hagstofu Íslands til að ákvarða aldursstöðlun (www.hagstofa.is). Í priðja lagi var tilfellum skipt í hópa eftir pví hvort ræktanir voru jákvæðar eða neikvæðar og hóparnir bornir saman með tilliti til aldurs og rannsóknarbreyta. Að lokum var kannað hvort um árstíðarsveiflu var að ræða í greiningum og var júni til ágúst flokkað sem sumar, september til nóvember sem haust, desember til febrúar sem vetur og mars til maí sem vor. Samanburður á miðaldri var gerður með Student's t-prófi par sem gert var ráð fyrir mismunandi dreifingu. Fjölpátta tvíkosta aðhvarfsgreining (multivariable binominal logistic regression) var bæði notuð til að kanna 
samband einkenna, rannsókna, árstíða og aldurs við niðurstöðu ræktana og til að kanna samband einkenna, blóðrannsókna og myndrannsókna milli beinasýkinga og liðasýkinga. Könnun á breytingu nýgengis á milli ára var gerð með Poisson-aðhvarfsgreiningu.

Fengin voru tilskilin leyfi frá Persónuvernd og Vísindasiðanefnd Landspítala auk sampykkis framkvæmdastjóra lækninga Landspítala og Sjúkrahússins á Akureyri.

\section{Niðurstöður}

Leit samkvæmt ICD greiningarkóðum í sjúkraskrám skilaði 253 tilfellum. Tveir einstaklingar komu fyrir tvívegis. Í öðru tilfellinu var um að ræða unga stúlku með beinasýkingu î mismunandi beinum með tveggja ára millibili. Í hinu tilfellinu var um að ræða táningsstúlku sem fékk beinbelg (bonecyst) í kjölfar beinasýkingar. Að fjórum árum liðnum greindist hún með sýkingu í beinbelgnum og fékk aftur fulla meðferð eins og um beinasýkingu væri að ræða. Вæði tilfellin voru pví talin sem nýjar sýkingar en ekki endursýkingar. Leit í skrá sýklafræðideildar Landspítala bætti ekki við fleiri tilfellum.

Alls uppfylltu 220 af 253 tilfellum skilyrði rannsóknarinnar. Af 220 sjúklingum voru 161 (73\%) með beinasýkingu og 59 (27\%) liðasýkingu. Í 59\% tilfella beinasýkinga og 44\% liðasýkinga tókst að greina orsakavald sýkingar. Í töflu I er samanburður á tilfellum með jákvæða og neikvæða ræktun. Einungis aldur tengdist marktækt niðurstöðu ræktana og voru neikvæðar ræktanir algengari hjá yngstu börnunum.

Aldursdreifing barnanna var frá 34 daga aldri að 17,7 ára aldri (mynd 1). Miðgildi aldurs barna með beinasýkingu var 6,1 ár (spönn 0,1-17,7). Aldursdreifingin er ekki normaldreifð og hefur nýgengi beinsýkinga tvo toppa, um eins ár aldur og um 11 ára aldur (mynd 1). Miðgildi liðasýkinga var 1,8 ár (spönn 0,8-17,0). Marktækur munur var á aldri pessara hópa $(\mathrm{p}=0,003)$. Kynjahlutfall beinasýkinga var 1,3 drengir á móti hverri stúlku og var hlutfallið 1,2 í liðasýkingum. Ekki var marktækur munur á kynjahlutföllum.

Nýgengi beina- og liðasýkinga sést á mynd 2 . Árlegt nýgengi sýkinganna samanlagt eykst marktækt á rannsóknartímabilinu $(p=0,019)$. Sundurliðun í aldurshópa og greining á milli beina- og liðasýkinga sýnir að aukningin skýrist fyrst og fremst af vaxandi nýgengi beinasýkinga í hópi 0-5 ára $(\mathrm{p}<0,001)$ (mynd 3). Nýgengi sýkinga par sem jákvæð ræktun lá fyrir breyttist ekki á tímabilinu en neikvæðar ræktanir jukust marktækt $(\mathrm{p}<0,001)$.

Hjá 219 af 220 börnum voru fengin sýni til
Tafla II. Niðurstöður ræktana beina- og liðasýkinga.

\begin{tabular}{|c|c|c|c|c|c|}
\hline \multicolumn{3}{|l|}{ Beinasýkingar $(\mathrm{N}=161)$} & \multicolumn{3}{|c|}{ Liðasýkingar ( $\mathrm{N}=59$ ) } \\
\hline Bakteríur $(\mathrm{N}=95)$ & Fjöldi & Hlutfall & Bakteríur $(\mathrm{N}=26)$ & Fjöldi & Hlutfall \\
\hline S. aureus & 62 & $65 \%$ & S. aureus & 7 & $27 \%$ \\
\hline Kingella kingea & 6 & $7 \%$ & Kingella kingea & 3 & $11 \%$ \\
\hline S. pyogenes & 6 & $7 \%$ & KNS & 3 & $11 \%$ \\
\hline $\begin{array}{l}\text { Kóagúlasa neikvæðir } \\
\text { staphýlókokkar (KNS) }\end{array}$ & 4 & $4 \%$ & S. pyogenes & 3 & $11 \%$ \\
\hline Corynebacterium sp. & 3 & $3 \%$ & S. pneumoniae & 2 & $8 \%$ \\
\hline S. pneumoniae & 2 & $2 \%$ & Streptókokkar af flokki C & 1 & $4 \%$ \\
\hline Bacillus sp. & 1 & $1 \%$ & N. mengingitidis & 1 & $4 \%$ \\
\hline S. mitis & 1 & $1 \%$ & S. mitis & 1 & $4 \%$ \\
\hline H. influenzae & 1 & $1 \%$ & Viridans streptókokkar & 1 & $4 \%$ \\
\hline Moraxella sp. & 1 & $1 \%$ & Streptococcus sp. & 1 & $4 \%$ \\
\hline Propionibacterium sp. & 1 & $1 \%$ & Flavobacterium sp. & 1 & $4 \%$ \\
\hline S. salivarius & 1 & $1 \%$ & S. pneumoniae + S. viridans & 1 & $4 \%$ \\
\hline Viridans streptókokkar & 1 & $1 \%$ & KNS + Bacillus sp. & 1 & $4 \%$ \\
\hline Streptókokkar af flokki C & 1 & $1 \%$ & & & \\
\hline S. aureus + KNS & 1 & $1 \%$ & & & \\
\hline S. aureus + S. mitis & 1 & $1 \%$ & & & \\
\hline S. aureus + Propionibacterium sp. & 1 & $1 \%$ & & & \\
\hline $\mathrm{KNS}+\mathrm{S}$. oralis $+\mathrm{S}$. marcecens & 1 & $1 \%$ & & & \\
\hline
\end{tabular}

ræktunar. Hjá sjúklingum með liðasýkingu var aflað liðvökva hjá 57 tilfellum af 59, en hjá peim tveimur sem ekki voru tekin úr liðvökvasýni var ræktað blóð. Í hópi barna með beinasýkingar voru gerðar 124 ástungur á bein og liði en blóð var sent í ræktun hjá 136 tilfellum af 161. Hjá einu barni með beinasýkingu var ekkert sýni tekið til ræktunar. Í bæði beina- og liðasýkingum var $S$. aureus algengasti orsakavaldurinn. Niðurstöður ræktana má sjá í töflu II. Dreifing sýkingarvalda

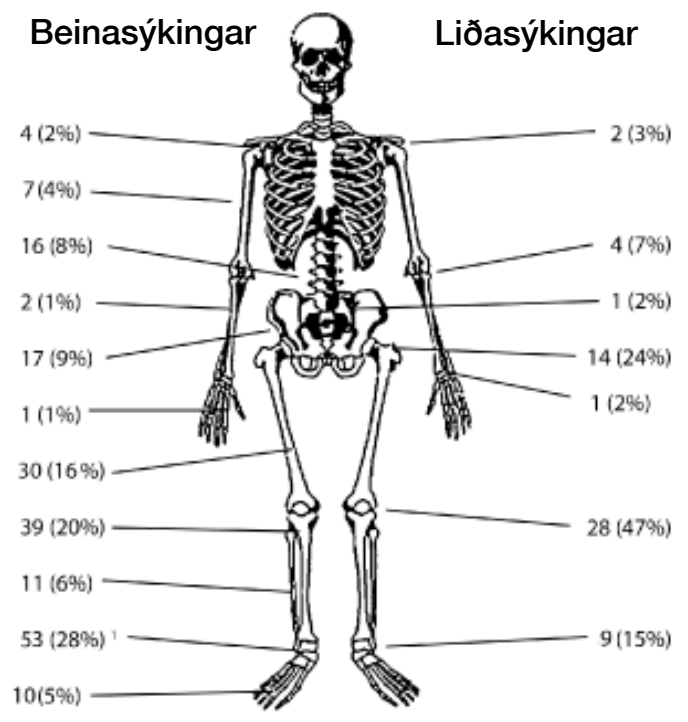

Mynd 3. Staðsetning sýkinga í beina- og liðasýkingum. Í sumum tilfellum var sýking í fleiri en einu beini.

1. Heildarfjöldi sýktra beina í ökkla. 
Tafla III. Einkenni og rannsóknir einstaklinga með beina- og liðasýkingar.

\begin{tabular}{|c|c|c|}
\hline & Beinasýking $(N=161)$ & Liðasýking ( $N=59)$ \\
\hline \multicolumn{3}{|l|}{ Almennt } \\
\hline Lengd einkenna (miðtala (spönn)) & $5(0-365)$ dagar $\dagger^{\star}$ & $2(0-15)$ dagar * \\
\hline Verkur & $151 / 161(94 \%)$ & $51 / 59(86 \%)$ \\
\hline Starfsbilun & $143 / 161(89 \%)$ & $55 / 59(93 \%)$ \\
\hline Bólga & 77/161 (48\%) & $41 / 59(69 \%)$ \\
\hline Roði & $63 / 161(39 \%)$ & $23 / 59(39 \%)$ \\
\hline Hiti (miðgildi (spönn)) & $38,0(36-40,7)$ & $38,0(36,5-40,7)$ \\
\hline \multicolumn{3}{|l|}{ Blóðrannsóknir (miðgildi (spönn)) } \\
\hline Hvít blóðkorn (x10\%/L) & $12,4(3,9-32,1)^{\star \star}$ & $10,3(5,3-26,0)^{\star \star}$ \\
\hline $\mathrm{CRP}(\mathrm{mg} / \mathrm{L})$ & $32(0-232)$ & $28(3-187)$ \\
\hline Sökk (mm/klst) & $31(1-102)$ & $30(1-90)$ \\
\hline \multicolumn{3}{|c|}{ Myndrannsóknir (jákvæðar/framkvæmdar) } \\
\hline Röntgenmynd & $43 / 134(32 \%)$ & $22 / 47(47 \%)$ \\
\hline Ísótóparannsókn & $111 / 121(92 \%)$ & $27 / 30(90 \%)$ \\
\hline Ómun & 9/39 (23\%) & $11 / 14(78 \%)$ \\
\hline Segulómun & $37 / 37(100 \%)$ & $3 / 4(75 \%)$ \\
\hline
\end{tabular}

† Ólíklegt er að beinasýking geti staðið i 365 daga án greiningar, byggt er á sjúkraskrárgögnum. ${ }_{*}^{*} \mathrm{p}=0,031$ (OR $\left.=0,82 ; \mathrm{Cl} 95 \% \quad 0,68-0,98\right)$

${ }^{* *} \mathrm{p}=0,031(\mathrm{OR}=0,82 ; \mathrm{Cl} 95 \%$ 0,68-0,98)

$\mathrm{p}=0,02(\mathrm{R}=1,14 ; \mathrm{Cl} 95 \% 1,02-1,28)$
Ekki var marktækur munur á öđrum gildum.

Ekki var marktækur munu
$\mathrm{CRP}=\mathrm{C}$ reactive protein af aukningu í nýgengi beinasýkinga hjá börnum á aldrinum 0-5 ára. Aukning á nýgengi beina- og liðasýkinga í bandarískri rannsókn frá árinu 2006 var tengd við fjölgun methicillin-ónæmra stofna S. Aureus. ${ }^{17}$ Sama skýringin á ekki við í okkar rannsókn par sem tilfellum með jákvæða ræktun fjölgar ekki. Pvert á móti standa pau í stað en tilfellum með neikvæða ræktun fjölgar marktækt. Aukning nýgengis er pví helst bundin við yngstu börnin með neikvæðar ræktanir. Pessa aukningu má skýra á nokkra vegu. Í fyrsta lagi að beinaog liðasýkingar séu ofgreindar pegar líður á rannsóknartímabilið, sem verður að teljast ólíklegt par sem enginn marktækur munur reyndist vera á einkennum og rannsóknum einstaklinga með jákvæðar eða neikvæðar ræktanir. Í öðru lagi kann raunverulegum sýkingum að hafa fjölgað par sem orsakavaldur greinist ekki. Skipta má pessum flokki í prennt. Mögulegt er að notkun sýklalyfja fyrir greiningu hafi aukist yfir tímabilið og gæti pað hafa valdið aukningu á neikvæðum ræktunum. Upplýsingar um notkun sýklalyfja fyrir ræktun voru ekki tiltækar í sjúkraskrám og pví ekki hægt að fullyrða um áhrif pessa páttar í rannsókninni. Ennfremur gætu breytingar á ræktunaraðferðum haft áhrif á greiningu en par sem ræktunaraðferðir breyttust ekki á tímabilinu er ólíklegt að pað skýri fyrrnefnda aukningu á tilfellum með neikvæða ræktun. Að lokum væri möguleiki að sýkill eða sýklar sem greinast illa eða ekki séu í sókn. Sýnt hefur verið fram á að hefðbundnar ræktunaraðferðir vangreini tilfelli beina- og liðasýkinga pegar borið er saman við greiningu byggða á fjölliðunarhvarfi (polymerase chain raction, $P C R$ ) sem greinir $16 \mathrm{~S}$ ribósómal DNA. Pegar slíkt hvarf er notað í rannsóknum á beina- og liðasýkingum hefur fjöldi K. kingae sýklagreininga vaxið um meira en helming. ${ }^{8}$, ${ }^{11}$ Sú tilgáta að sýkill eða sýklar sem erfitt er að einangra með hefðbundnum ræktunaraðferðum sé í vaxandi mæli að valda pessum sýkingum er pví möguleg.

Erlendar rannsóknir hafa sýnt fram á að töluverður fjöldi K. kingae sýkinga getur verið ógreindur með peim ræktunaraðferðum sem notaðar eru hér á landi fyrir beina- og liðasýkingar. ${ }^{8}$ 11, 18 Pví væri ástæða til að skoða rannsóknargögn hópsins með neikvæða ræktun nánar. Í rannsókn okkar kom fram afgerandi munur á aldursdreifingu barna með staðfesta ræktun og peirra par sem bakteríur ræktuðust ekki. Tilfelli par sem ræktun var neikvæð hafa miðtölu aldurs 1,8 ár en í hópnum par sem ræktun var jákvæð var miðtalan 8,5 ár. Svipuð tilhneiging sést pegar hlutfall undir fjögurra ára er kannað pó munurinn sé ekki marktækur. Hlutfall undir 
fjögurra ára var 71\% í hópi peirra með neikvæða ræktun en 34\% í hópi peirra með jákvæða ræktun. Í erlendum rannsóknum er miðtala aldurstilfella K. kingae sýkinga 1,2-1,5 ár og greinast 96-98\% peirra fyrir fjögurra ára aldur.8, 9, 11 Rannsóknir sem snúa að nýgengi peirra sem bera $K$. kingae í öndunarvegi sýna jafnframt að hæsta beratíðni er á aldrinum sex mánaða til fjögurra ára. ${ }^{19}$ Aldur einstaklinga með neikvæða ræktun í okkar rannsókn samrýmist aldri K. kingae sýkinga. Af öllum tilfellum liða- og beinasýkinga par sem ræktanir voru neikvæðar greindust $41 \%$ á haustin, af öllum tilfellum par sem ræktanir voru jákvæðar voru hins vegar $32 \%$ greind á haustin. Petta er ekki marktækur munur en pó athyglisvert í ljósi pess að í rannsóknum hefur komið fram að 51\% allra K. kingae sýkinga greinast á haustin. ${ }^{11}$ Pessi tilhneiging var enn sterkari í okkar rannsókn pví um $67 \%$ K. kingae sýkinga greindust á haustin.

Aldursdreifing beina- og liðasýkinga í okkar rannsókn samrýmist niðurstöðum erlendra rannsókna. ${ }^{6}$ Flestar liðasýkingar (66\%) greindust fyrir priggja ára aldur en einungis $40 \%$ beinasýkinga greinist á sama aldursbili. Munurinn á aldursdreifingu beinasýkinga og liðasýkinga er að beinasýkingar toppa á tveimur aldursbilum og er seinni toppurinn á aldrinum 9-12 ára. Petta má útskýra með vexti beina pví að vöxturinn er mestur á fyrstu aldursárunum og síðan á árunum 9-12 ára. ${ }^{20}$ Kynjahlutfall er 1,2 drengir á móti hverri stúlku, sem er sambærilegt við pað sem finnst í erlendum rannsóknum. ${ }^{6,9}$

Algengustu einkenni beina- og liðasýkinga í rannsókninni voru verkir og starfsbilun (functio laesa). Bólga var einnig algengt einkenni. Athyglisvert er að einungis helmingur barna var með hita $\left(38^{\circ} \mathrm{C}\right)$ fyrir greiningu og telst hiti pví vart gott greiningarmerki. Talning hvítra blóðkorna og mælingar á CRP skýra og sökki voru ekki sérlega gagnlegar rannsóknir til greiningar á beina- og liðasýkingum par sem pær eru ekki afgerandi. Blóðrannsóknargildi voru í samræmi við niðurstöður erlendra rannsókna. ${ }^{6,11}$

Algengasti orsakavaldur beinasýkinga var S. aureus sem greindist hjá $65 \%$ tilfella. $S$. aureus var einnig algengasta orsök liðasýkinga (22\%). Petta er í samræmi við sambærilegar erlendar rannsóknir. ${ }^{1,6}$ Enn sem komið er hafa MÓSA ekki greinst í beina- og liðasýkingum á Íslandi eins og raunin er víða erlendis. ${ }^{6,17}$ Næst algengasta baktería, bæði beina- og liðasýkinga, var K. kingae, sem verður að teljast athyglisvert par sem hún greindist fyrst á Íslandi árið $1995 .{ }^{12}$ Myndrannsóknir eru afar gagnlegar til greiningar á beina- og liðasýkingum og var notkun peirra að mestu leyti sambærileg við niðurstöður erlendra rannsókna. ${ }^{21,22}$ Röntgenmyndir eru mikið notaðar en prátt fyrir lítið næmi við greiningu á beina- og liðasýkingu eru pær mjög gagnlegar til útilokunar annarra greininga. Ísótóparannsókn er mun næmari rannsókn og hentar vel til að leita að sjúkdómshreiðrum. Segulómun er næmasta myndrannsóknin fyrir beinasýkingar en í okkar rannsókn var hún einungis framkvæmd í 25\% tilfella. Erfitt er að meta næmi segulómana í liðasýkingum par sem sú rannsókn var gerð á fáum einstaklingum. Fjöldi segulómana óx til muna yfir tímabilið (gögn ekki sýnd).

Rannsóknin hefur sýnt að nýgengi liða- og beinasýkinga barna vex í yngsta aldurshópnum, ef til vill af völdum sýkla sem ræktast illa eins og K. kingae. Færa má rök fyrir pví að pörf sé á næmari sýklafræðilegum rannsóknum hér á landi hjá einstaklingum með einkenni um beina- eða liðasýkingar en neikvæðar hefðbundnar ræktanir.

\section{Pakkir}

Andrea Andrésdóttir, yfirlæknir barnadeildar Sjúkrahúss Akureyrar, aðstoðaði við öflun gagna á Akureyri. Ritarar Barnaspítala Hringsins og starfsfólk skjalasafns Landspítala við Vesturhlíð aðstoðuðu við skjalasöfnun.

\section{Heimildir}

1. Kao HC, Huang $\mathrm{YC}$, Chiu $\mathrm{CH}$, et al. Acute hematogenous osteomyelitis and septic arthritis in children. J Microbiol Immunol Infect 2003; 36: 260-5.

2. Elasri MO, Thomas JR, Skinner RA, et al. Staphylococcus aureus collagen adhesin contributes to the pathogenesis of osteomyelitis. Bone 2002; 30: 275-80.

3. Mandell GL, Bennett JE, Dolin R, editors. Principles and Practice of Infectious Diseases. 6th ed. Elsevier, Philadelphia 2005.

4. Morrissy RT, Haynes DW. Acute hematogenous osteomyelitis: a model with trauma as an etiology. J Pediatr Orthop 1989; 9: 447-56.

5. Axford JS. Joint and bone infections. Medicine 2006; 34: 40512.

6. Goergens ED, McEvoy A, Watson M, Barrett IR. Acute osteomyelitis and septic arthritis in children. J Paediatr Child Health 2005; 41: 59-62.

7. Feigin RD, Cherry JD, editors. Textbook of Pediatric Infectious Diseases. 4th ed. W.B. Saunders Company, Philadelpia 1998.

8. Verdier I, Gayet-Ageron A, Ploton C, et al. Contribution of a broad range polymerase chain reaction to the diagnosis of osteoarticular infections caused by Kingella kingae: description of twenty-four recent pediatric diagnoses. Pediatr Infect Dis J 2005; 24: 692-6.

9. Moumile K, Merckx I, Glorion C, Pouliquen IC, Berche $\mathrm{P}$, Ferroni A. Bacterial aetiology of acute osteoarticular infections in children. Acta Paediatr 2005; 94: 419-22.

10. Yagupsky P. Kingella kingae: from medical rarity to an emerging paediatric pathogen. Lancet Infect Dis 2004; 4: 35867.

11. Chometon S, Benito Y, Chaker M, et al. Specific real-time polymerase chain reaction places Kingella kingae as the most common cause of osteoarticular infections in young children. Pediatr Infect Dis J 2007; 26: 377-81.

12. Birgisson H, Steingrímsson Ó, Guðnason. Kingella kingae beina- og liðsýkingar í börnum: Sex sjúkratilfelli af Barnaspítala Hringsins. Læknablaðið 2000; 86: 516-9. 
13. Sheftel TG, Mader JT. Randomized evaluation of ceftazidime or ticarcillin and tobramycin for the treatment of osteomyelitis caused by gram-negative bacilli. Antimicrob Agents Chemother 1986; 29: 112-5.

14. Tetzlaff TR, McCracken GH, Jr., Nelson JD. Oral antibiotic therapy for skeletal infections of children. II. Therapy of osteomyelitis and suppurative arthritis. J Pediatr 1978; 92 : 485-90.

15. Le Saux N, Howard A, Barrowman NJ, Gaboury I, Sampson M, Moher D. Shorter courses of parenteral antibiotic therapy do not appear to influence response rates for children with acute hematogenous osteomyelitis: a systematic review. BMC Infect Dis 2002; 2: 16.

16. Bachur R, Pagon Z. Success of short-course parenteral antibiotic therapy for acute osteomyelitis of childhood. Clin Pediatr 2007; 46: 30-5

17. Arnold SR, Elias D, Buckingham SC, et al. Changing patterns of acute hematogenous osteomyelitis and septic arthritis: emergence of community-associated methicillin-resistan Staphylococcus aureus. J Pediatr Orthop 2006; 26: 703-8.
18. Ilharreborde $\mathrm{B}$, Bidet $\mathrm{P}$, Lorrot $\mathrm{M}$, et al New real-time PCR-based method for Kingella kingae DNA detection: application to samples collected from 89 children with acute arthritis. J Clin Microbiol 2009; 47: 1837-41.

19. Dodman T, Robson J, Pincus D. Kingella kingae infections in children. J Paediatr Child Health 2000; 36: 87-90.

20. Bass S, Delmas PD, Pearce G, Hendrich E, Tabensky A, Seeman E. The differing tempo of growth in bone size, mass, and density in girls is region-specific. J Clin Invest 1999; 104: 795-804.

21. Blickman JG, van Die CE, Rooy JW. Current imaging concepts in pediatric osteomyelitis. Eur Radiol 2004; 14 Suppl: L55-L64.

22. Capitanio MA, Kirkpatrick JA. Early roentgen observations in acute osteomyelitis. Am J Roentgenol Radium Ther Nucl Med 1970; 108: 488-96.

\section{Bactrial osteomyelitis and arthritis in Icelandic children 1996-2005}

Objective: The main objective was to determine the incidence and causative pathogens of osteomyelitis and septic arthritis in Icelandic children, as well as presenting symptoms and diagnosis.

Methods: A nationwide retrospective review was done of all children $<18$ year old, 1996-2005. Subjects were divided into three equal age groups, $0-5,6-11$ and $12-17$ years old. Cultures were reviewed and postive and negative cases compared. Results: Over the study period 220 cases were identified, 161 osteomyelitis and 59 septic arthritis cases. The incidence increased significantly over the period $(p=0.019)$, mostly in the youngest age group $(p<0.001)$ with osteomyelitis. Incidence of cases with a pathogen identified was unchanged over the period while culture negative cases increased significantly $(p<0.001)$. Median age for osteomyelitis $(6,1$ years $)$ was higher than in cases of septic arthitis ( 1,8 years) $(p=0.003)$. $A$ pathogen was identified in $59 \%$ of cases with osteomyelitis and $44 \%$ with septic arthritis. S. aureus was most common ( $65 \%$ and $27 \%$, respectively) and $K$. kingae was second most common pathogen ( $7 \%$ and $11 \%$, respectively). Methicillin resistant $S$. aureus was not identified. The tibia and knee were the predominant sites for osteomyelitis and septic arthritis respectively.

Conclusions: An increased incidence was found in the youngest age group with osteomyelitis, especially in cases without a pathogen identified. The most commonly cultured pathogen was S. aureus, followed by K. kingae. A more sensitive technique to identify pathogens might be indicated in culture negative cases.

Masson AT, Gudnason Th, Jonmundsson GK, Erlendsdottir H, Kristinsson KG, Kristjansson M, Haraldsson A.

Bactrial osteomyelitis and arthritis in Icelandic children 1996-2005.

Icel Med J 2011; 97: 91-6

Key words: Osteomyelitis, septic arthritis, Staphylococcus aureus, Kingellae kingae, children.

Correspondence: Ásgeir Haraldsson, asgeir@landspitali.is

\section{Fræðsludagur heimilislækna 5. mars 2011}

Hinn árlegi fræðslu- og fagnaðardagur heimilislækna verður haldinn á Nordica Hótel fyrsta laugardag í mars.

Öldrunarlæknar og endurhæfingarlæknar eru sem fyrr hjartanlega velkomnir.

Fræðsludagurinn er sem áður skipulagður af FíH og styrktur af AstraZeneca.

Dagskrá hefst kl. 9.00

Nánari dagskrá verður send læknum sérstaklega.

Fræðslunefnd FíH

AstraZeneca 